\title{
The Relationship between Service Quality, Customer Satisfaction and Customer Loyalty: An Investigation in Vietnamese Retail Banking Sector
}

\author{
- Ngo Vu Minh, Nguyen Huan Huи
}

\begin{abstract}
This study develops and empirically tests the interrelationships between service quality, customer satisfaction, and customer loyalty in a retail banking context. Increasingly intense competitiveness and fundamental changes in the business environment nowadays are forcing firms to implement a customer-focused strategy which raises the importance of customer-related constructs such as customer satisfaction, service quality, and customer loyalty in explaining a firm's performance. In particular, they are essential for competitiveness in industries where the exchanges are complex and customers are closely involved in the decision-making process, such as the banking industry. In this study, first, a research model about the interrelationships between service quality, customer satisfaction, and customer loyalty is suggested. Then a survey is conducted with retail banking customers about these constructs, which results in 261 valid respondents. The hypotheses are then proposed and tested using confirmatory factor analysis (CFA) and the structural equation modelling technique (SME). The analysis reveals that service quality and customer satisfaction are important antecedents of customer loyalty and customer satisfaction mediates the effects of service quality on customer loyalty. These findings suggest that there are non-linear relationships between three constructs and emphasize the need to treat customer loyalty management as a process which includes plenty of factors interacting with each other.
\end{abstract}

Key words: service quality, customer satisfaction, customer loyalty, banking, competitive and mediators. JEL Classification: M10, M20, M31

\section{INTRODUCTION}

It might be well accepted nowadays that intensive competitiveness in terms of both quantity and quality makes it extremely difficult for a firm to differentiate itself from its competitors. Moreover, dynamic business environments and increasing customer power have pushed firms toward a customer-focused strategy, especially using new technology to build relationships with the customer (Ryding, 2010). As a result, excellent business processes and intangible assets such as brands, customer satisfaction, and powerful human resources might become the most essential sources of sustainable competitive advantages (Chien \& Tsai, 2012; Teece, 2007; Wang $\&$ Ahmed, 2007). These fundamental changes, together with the invisible and hard-to-observe characteristics of qualitative/non-financial measures, have raised the questions of whether nonfinancial measures such as customer satisfaction and job satisfaction have real and significant effects on firm performance and how they do it. Among them, customer loyalty has been consid- 
ered as one of the most important competitive edges in today's business environment, in which the purchasing power of the customer is increasing while companies have to encounter limitless challenges from their competitors (Pan, Sheng, \& Xie, 2012; Sharma, 2007). Therefore, for cost reduction and profit improvement reasons and to build sustainable competitiveness, maintaining long-term customer loyalty is a mandatory task. In this context, both practitioners and researchers have searched for the most important antecedents of customer loyalty. Many studies in the relationship marketing literature have demonstrated that customer satisfaction is one of the most popular determinants of customer loyalty (Flint, Blocker, \& Boutin, 2011; Mittal \& Kamakura, 2001; Tsai, Tsai, \& Chang, 2010). Although there is a consensus among researchers that satisfaction can be a basis for achieving loyalty, researchers also agree that the satisfaction-loyalty relationship should have more ingredients. In this stream of research, previous studies have developed and applied some theoretical and conceptual frameworks which can extend and elaborate the satisfaction-loyalty relationship, such as the Balanced Scorecard (BSC) and the Service-profit chain frameworks (Heskett, Jones, Loveman, Sasser Jr., \& Schlesinger, 2008; Kaplan \& Norton, 1992; Tayler, 2010). These frameworks view customer loyalty and financial sequences as the top and final sequences of a system and proposed completed set of cause-and-effects relationships between different organizational factors such as a learning organization, excellent internal service, employee satisfaction, and excellent business processes to achieve them. Among these factors, excellent business processes which lead to product/service quality can be seen as the direct factors impacting on customer satisfaction and customer loyalty (Brady, Cronin, \& Brand, 2002; Chu, Lee, \& Chao, 2012). If these relationships are valid, managers can understand the sources of customer satisfaction and customer loyalty more clearly in order to give better service to the customer and improve the firm's financial performance. Therefore, using the context of a new banking service, this study develops and empirically tests the interrelationships between service quality, customer satisfaction, and customer loyalty. The main objective of this study is to confirm and provide new empirical evidence about the interrelationships between service quality, customer satisfaction and customer loyalty which are suggested in the above-mentioned conceptual frameworks.

The rest of this study is divided into sections, as follows. First, the next section provides the theoretical background and develops the hypotheses for this study. Second, the research methodology is developed and put into use. Third, in order to test the hypotheses, data analysis and results are presented. Finally, the findings of this study are concluded and managerial implications and limitations are discussed

\section{THEORETICAL BACKGROUND AND HYPOTHESES}

\subsection{Customer loyalty}

Customer loyalty can be defined as the closest step to the repurchasing behaviour of customers. Customer loyalty has usually been referred to as a consequence of all the experiences that a customer has with a service/product provider (Mascarenhas, Kesavan, \& Bernacchi, 2006). The experiences might include physical interactions, emotional involvements, and value chain moments, according to Mascarenhas et al. (2006). In term of loyalty's consequences, a shift to a 
loyalty strategy from an only-satisfaction strategy can substantially increase customer retention and reduce marketing costs (Stan, Caemmerer, \& Cattan-Jallet, 2013). Camarero et al. (2005) found from a Spanish case study that customer loyalty has positive impacts on both a firm's market performance and its economic performance. Generally, customer loyalty has been referred to as the link between customer attitude, repeat purchasing, and financial performance (Heskett et al., 2008). In terms of the antecedents of customer loyalty, a number of constructs have been proposed by previous studies. Yee, Yeung, and Cheng (2010) found that employee loyalty, service quality, and customer satisfaction have a positive influence on customer loyalty in a high-contact service industry. In addition, according to Oliver (1999), loyalty can be developed through different phases, which are cognitive sense, affective sense, conative manner, and finally behavioural manner. The first three phases are usually referred as attitudinal loyalty which are dependent on the experiences that customers have with service providers (overall satisfaction). Completing these three stages can lead to the behavioral loyalty as the final stage. This evolvement process of customer loyalty is confirmed by a meta-analysis about the antecedents of customer loyalty by Pan, Sheng and Xie (2012). In this study, by conducting a meta-analysis, the authors also found the empirical evidences supporting that customer satisfaction, trust, commitment and loyalty program memberships have positive influences on customer loyalty. In addition, the productrelated attributes such as quality, value, brand reputation and switching cost also determine level of loyalty from customers. In this study, the author attempt to evaluate the relationships between customer loyalty and two other constructs which are popular in relationship marketing, especially in service context industry, customer satisfaction and service quality.

\subsection{Service quality and customer satisfaction}

Customer satisfaction is becoming one of the most essential objective which any firm seeking for long-term relationship with customer considers as the top priority. In retail banking context where the contacts with customers are one of the most core business processes, customer satisfaction is becoming the key for successful (Belas \& Gabcova, 2014; Belas, Cipovova \& Demjan, 2014; Chavan \& Ahmad, 2013). One of the main element determining customer satisfaction is the customer's perception of service quality. Customer satisfaction is described as the result of a comparison of the customers' expectations and his or her subsequent perceived performance of service quality (Herington \& Weaven, 2009). According to this conceptualization, perceived service quality is one of the antecedents to overall customer satisfaction. Previous studies showed the evidence support this relationship between customer satisfaction and service quality (Yee, Yeung, \& Cheng, 2011). Even though, there are also debates about the causal relationship between customer satisfaction and service quality. Specifically, there are three major positions about this relationship in the literature (Brady et al., 2002). First, as indicated above, service quality is described as an antecedents to customer satisfaction (Naik, Gantasala, \& Prabhakar, 2010; Olorunniwo, Hsu, \& Udo, 2006). Second, some researchers suggest that customer satisfaction is the cause of service quality (Bitner, 1990). The third position of the service quality- satisfaction relationship argues that neither satisfaction nor service quality may be antecedent to the other (Dabbolkar, 1995; McAlexander, Kaldenberg, \& Koenig, 1994). In general, although there is the lack of consensus about the conceptualization of the service quality- satisfaction relationship, service quality is an antecedent to customer satisfaction is considered as dominant position 
in recent research, especially in service context industry like banking (Akhtar, Hunjra, Akbar, Kashif-Ur-Rehman, \& Niazi, 2011; Cameran, Moizer, \& Pettinicchio, 2010) . In this study, one of the objectives is to empirically test this relationship. Therefore, the following hypothesis is offered:

$\mathrm{H}_{1}$ : In banking industry context, overall service quality is the antecedent of customer satisfaction.

\subsection{Customer satisfaction and customer loyalty}

Although customer satisfaction and customer loyalty are distinct constructs, they are highly correlated (Gelade \& Young, 2005; Silvestro \& Cross, 2000). Customer loyalty is referred as the final consequences of the overall and cumulative experience which customers have with a firm (Brunner, Stöcklin, \& Opwis, 2008). Customer satisfaction can lead to customer loyalty because people tend to be rational and risk-adverse so that they might have a tendency to reduce risk and stay with the service providers which they already had good experience with. Actually, customer satisfaction has been suggested to be an antecedent of loyalty in service context in previous studies (Belas \& Gabcova, 2016; Coelho \& Henseler, 2012; Lam, Shankar, Erramilli, \& Murthy, 2004; Mittal \& Kamakura, 2001). There are also many type of relationship between customer satisfaction and customer loyalty suggested such as satisfaction is the core of loyalty, satisfaction is one of the necessary components of loyalty, satisfaction and loyalty are the components of ultimate loyalty and satisfaction as the starting point of loyalty (Munari, Ielasi \& Bjetta, 2013). In addition, the relationship between customer satisfaction and customer loyalty might be nonlinear. Heskett et al. (2008) suggested that customer loyalty should improve dramatically when customer satisfaction overcome a certain level. In sum, the dominant proposition is that satisfaction is an essential necessary parts to achieve customer loyalty. In addition, as it presented here in early part, service quality is assumed to be an antecedent of customer satisfaction. Therefore, it can be interesting to test the relationship between service quality and customer loyalty with customer satisfaction as the mediator of this relationship. In this stream of research, most of the studies confirm that there is positive relationship between service quality and customer loyalty and customer satisfaction is usually the mediator between them (Chodzaza \& Gombachika, 2013; Chu et al., 2012). In banking sector context, the service quality- loyalty relationship is also supposed to be mediates by customer satisfaction by previous studies (Hassan, Malik, Imran, Amna, \& Abbas, 2013; Lee \& Moghavvemi, 2015). In addition, in a meta-analysis about customer loyalty antecedents, the results show that the effect of quality on loyalty become stronger over time (Pan et al., 2012). As a result of the analysis, the following hypotheses are raised for testing:

$\mathrm{H}_{2}$ : In banking industry context, customer satisfaction is the antecedent of customer loyalty.

$\mathrm{H}_{3}$ : In service banking context, overall service quality is the antecedent of customer loyalty.

$\mathrm{H}_{4}$ : In service banking context, customer satisfaction fully/partly mediates the relationship between service quality and customer loyalty. 


\section{RESEARCH METHODOLOGY}

\subsection{Data collection and sample}

A questionnaire is developed by the author for collection data from retail banking customers in Vietnam. Retail banking customers have to use at least one service from one bank in Vietnam. The sample of retail banking customers was collected on the basis of convenience sampling. Emails with a survey instrument were sent by author to a total 850 customers of 11 retail banks in Vietnam. There were 273 customers participated in the research. Among responds returned, there were 12 responses were eliminated because of uncompleted answers. Finally, there are usable 261 responses were collected and used, which make 30\% successful response rate.

The main demographic features of the respondents are described as followed. There are 102 respondents are males (39\%) and 159 are female (61\%). Respondents whose age is from 20 to 30 and 30 to 45 constitute $46.2 \%$ and $51.4 \%$ of the sample population. The average income per month of respondents varied widely from $\$ 200$ to more than $\$ 1500$. Almost half of the respondents have the average income per month around $\$ 400$ to $\$ 800(46 \%)$, only small portion of respondents have average income per month from $\$ 800$ to more than $\$ 1500$ (16\%). Most of the respondents have college or university degree $(80 \%)$ or have postgraduate degrees $(14.5 \%)$. In addition, regarding the services that respondents use the most from their banks, most of the respondents use the debit/credit card and payment services (50\%), transferring money services $(25 \%)$, or deposit and saving service $(15 \%)$.

\subsection{Measures}

For this study, the measurement scales and the indicators are adopted from previous studies. These measurements scales are validated in prior researches, especially in the context of financial service (Brady et al., 2002; Colgate \& Lang, 2001; Cronin Jr., Brady, \& Hult, 2000; Jones, Mothersbaugh, \& Beatty, 2000). Modifications and translations are made to transform the measurement scale to be readable for average retail banking customer in Vietnam and reflect the context of the retail banking industry in Vietnam. In general, the respondents are asked to give their agreement or disagreement with the statement. Respondents give their opinion for each statement through 7-point Likert scale with 1 to indicate "strongly disagree" and 7 to indicate "strongly agree".

In order to investigate the mediating role of customer satisfaction in the service quality- loyalty relationship, the service quality is approached as an overall construct. Therefore, four items for measuring overall service quality construct adopted from Brady et al. (2002) are used. Three items which are adopted from Cronin et al. (2000) are used to measure the overall customer satisfaction. There items are used to measure the customer loyalty including 1 item about the word-of-mouth intention and 2 items about repurchase intention. These three items are also adopted from Cronin et al. (2000). 


\section{DATA ANALYSIS AND RESULT}

The proposed mediating relationship between overall service quality, customer satisfaction, and customer loyalty are tested by structure equation modelling using Amos 22.0. The confirmatory factor analysis (CFA), reliability and validity analysis are performed to assess the adequacy of the measurement model. Then, the structural model is tested to assess the relationships within proposed research model in Figure 1, especially for the mediating effects of customer satisfaction.

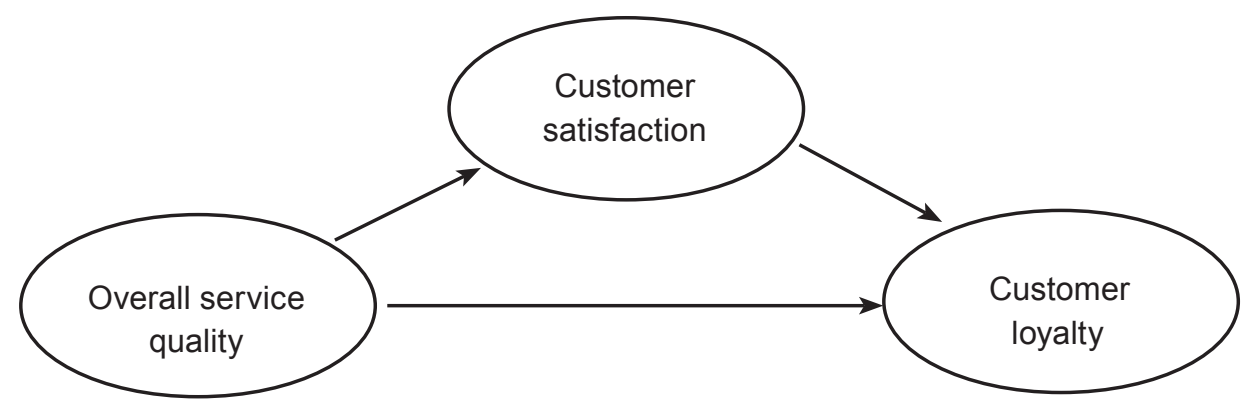

Fig. 1 - Research model (Source: Own research)

\subsection{Testing of the measurement model}

CFA is executed to see how the research model in the Figure 1 fit with the data collected from the samples (Anderson \& Gerbing, 1988). Previous studies suggest to use more than one goodness-of-fit index to evaluate the model fit of the proposed model. Therefore, in this study set of goodness-of-fit indices are used. Specifically, the Chi-square is significant at 0.05 level $\chi^{2}=$ $48.345(p=0.03)$ and the relative Chi-square $\left(\chi^{2} / d f=1.511\right)$ (smaller than 2$)$ show the acceptable fit with large data analysis. Other indices show the good fit for the research model. The normed fit index $(\mathrm{NFI})=0.98$, the comparative fit index $(\mathrm{CFI})=0.993$, the Tucker-Lewis coefficient index $(\mathrm{TLI})=0.99$ (NFI, CFI, TLI all > 0.95); the root mean square residual $(\mathrm{RMR})=0.033$ and root mean square error of approximation $($ RMSEA) $=0.044$ (both $<0.08$ ). In sum, the data collected from the sample of retail banking customers are fit well with the proposed research model.

\subsection{Construct reliability and validity}

Construct reliability refers to the degree to which a set of indicators consistently and stability reflect a given constructs. Cronbach's alpha is the most commonly used for assessing the reliability of a construct. The Cronbach's alpha of each construct in the research model is presented in Table 1. As indicated in Table 1, all the Cronbach's alpha for all constructs exceeds 0.80 , satisfying the general recommended level of 0.70 for the research indicators (Cronbach, 1951).

Convergence validity refers to how well different indicators for measuring constructs converge, indicating that a single dimension of meaning is being measured. Convergent validity can be assessed by examining the factor loading and the average variance extracted (AVE) of the constructs (Fornell \& Larcker, 1981). All the indicators had significant loading onto the constructs 
which they expected to measure $(p<0.01)$. Moreover, as presented in Table 1 , the AVE for each construct is greater than 0.50 , which indicate the convergence validity of the constructs.

Discriminant validity refers to the fact that indicators for different constructs should not be so highly correlated across constructs which can be lead to the constructs overlap. Discriminant can be examined by comparing the construct's square root of AVE with its square correlation with other constructs (Fornell \& Larcker, 1981). As presented in Table 2, the square root AVE value of each construct are greater than its square correlation with other constructs, which support the discriminant validity of the constructs.

Tab.1 - Convergent Validity. Source: Own research

\begin{tabular}{|c|c|c|c|c|c|}
\hline Constructs & Indicator & $\begin{array}{c}\text { Standardize } \\
\text { estimates }\end{array}$ & P value & $\begin{array}{c}\text { Cronbach's } \\
\text { alpha }\end{array}$ & AVE \\
\hline \multirow{4}{*}{$\begin{array}{l}\text { Service } \\
\text { Quality }\end{array}$} & SQ1 & 0.872 & $*$ & \multirow{4}{*}{0.890} & \multirow{4}{*}{0.672} \\
\hline & SQ2 & 0.835 & $*$ & & \\
\hline & SQ3 & 0.764 & $*$ & & \\
\hline & SQ4 & 0.832 & * & & \\
\hline \multirow{3}{*}{$\begin{array}{l}\text { Customer } \\
\text { satisfaction }\end{array}$} & CS1 & 0.862 & $*$ & \multirow{3}{*}{0.923} & \multirow{3}{*}{0.803} \\
\hline & $\mathrm{CS} 2$ & 0.906 & $*$ & & \\
\hline & CS3 & 0.880 & * & & \\
\hline \multirow{3}{*}{$\begin{array}{l}\text { Customer } \\
\text { loyalty }\end{array}$} & CL1 & 0.916 & * & \multirow{3}{*}{0.930} & \multirow{3}{*}{0.817} \\
\hline & CL2 & 0.888 & $*$ & & \\
\hline & CL3 & 0.909 & * & & \\
\hline
\end{tabular}

Tab. 2 - Discriminant Validity. Source: Own research

\begin{tabular}{|l|c|c|c|}
\cline { 2 - 3 } \multicolumn{1}{c|}{} & Service quality & Customer satisfaction & Customer loyalty \\
\hline Service quality & 0.820 & & \multicolumn{1}{|c|}{} \\
\hline Customer satisfaction & 0.802 & 0.896 & 0.904 \\
\hline Customer loyalty & 0.813 & 0.885 & \\
\hline
\end{tabular}

\subsection{Testing the hypothesis}

Path analysis of structural equation modeling is used to test the hypotheses about the relationship between service quality, customer satisfaction, and customer loyalty. The research model as shown Figure 1 is used to test the customer satisfaction mediating role in the service quality- loyalty relationships. Model fit indices for base model show a good fit $\left(\chi^{2}=54.6, \mathrm{p}\right.$-value $=0.14, \chi^{2} / d f=1.606$; NFI $=0.977$; CFI $\left.=0.991 ; \mathrm{RMR}=0.05 ; \mathrm{RMSEA}=0.048\right)$. The result of path analyses for the research model are shown in Table 3. As presented in Table 3, hypotheses $\mathrm{H}_{1}, \mathrm{H}_{2}$ and $\mathrm{H}_{3}$ are supported in the base model when all the paths, service quality to customer satisfaction, customer satisfaction to customer loyalty, service quality to customer loyalty, are statistically significant (all p-values $<0.001)$. 
For investigating the statistical significant mediation effect of customer satisfaction, the bootstrapping approach is used because it does not impose distributional assumptions (Preacher \& Hayes, 2004). The bootstrapping analyses are shown in Table 4. The indirect effect of service quality to customer loyalty is statistically significant ( $\mathrm{p}$-value $<0.001)$. Hypothesis $\mathrm{H}_{4}$ is supported.

Tab. 3 - Standardized path coefficients of the structural model. Source: Own research

\begin{tabular}{|l|c|c|}
\hline Relationships & Estimation & Hypotheses testing \\
\hline SQ -> CS & $0.900 * * *$ & Support $\mathrm{H}_{1}, \mathrm{H}_{4}$ \\
\hline CS -> CL & $0.744 * * *$ & Support $\mathrm{H}_{2}, \mathrm{H}_{4}$ \\
\hline SQ -> CL & $0.400 * * *$ & Support $\mathrm{H}_{3}, \mathrm{H}_{4}$ \\
\hline
\end{tabular}

Note. SQ: Service quality; CS: Customer satisfaction; CL: Customer loyalty; $* * *=\mathrm{p}$-value $<0.01$; ns $=$ not significant.

Tab. 4 - Bootstrapping results for testing mediation effects. Source: Own research

\begin{tabular}{|l|c|c|c|}
\hline Hypotheses mediations & Direct effect & Indirect effect & Result \\
\hline SQ -> CS -> CL & $0.400 * * *$ & $0.528 * * *$ & $\begin{array}{c}\text { Partial mediation. } \\
\mathrm{H}_{4} \text { supported }\end{array}$ \\
\hline
\end{tabular}

$* * *=\mathrm{p}$-value $<0.01$

\section{DISCUSSION}

Our findings contribute to the discussion about the complex interrelationship between service quality, customer satisfaction, and customer loyalty. This study provides empirical evidence of their relations to each other as proposed in the research model. This study adopts the view that the relationship between service quality, customer satisfaction, and customer loyalty is complex and contributes new empirical evidence of these interrelationships. The major contribution of this study is to bring up some of the most popular constructs in the relationship marketing literature, namely, service quality, customer satisfaction, and customer loyalty, together in order to test their interrelationships in a very different context. Most of the previous research studies about their interrelationships have been conducted in Western and developed countries, which are generally recognized as having many differences from Eastern and developing countries in terms of cultures and customers' needs, which are the basis for the relationship between customers and service providers. Vietnam, as an Asian country and developing economy, has very specific characteristics differentiating it from other contexts used in previous studies to examine the interrelationship between service quality, customer satisfaction, and customer loyalty. First, for historical reasons, the Vietnamese economy has been experiencing a transformation from a state-controlled economy to a market-driven economy for just over 20 years. Because of this fact, the premises of competitive advantages and relationship marketing in particular are new practices for both companies and customers in Vietnam. Nevertheless, this study shows that they are applicable to the Vietnamese context regarding the interrelationship between service quality, 
customer satisfaction, and customer loyalty. Second, the Vietnamese retail banking industry in particular is very different from its counterparts in Western countries or developed economies with regard to how banks compete with each other. Banks in Vietnam are considered one of the important areas to invest in sources for investing, besides their traditional role of a safe place for saving money. Therefore, Vietnamese banks compete largely by means of the prices of their services or interest rates for deposits and loans. Although in recent years Vietnamese banks have been heading toward building a sustainable competitive advantage through the quality of their product/service and close relationships with their customers, this transformation needs time and price is still the top priority of most of the banks for competing. Therefore, the Vietnamese economy and retail banking industry are very different from the contexts used in previous studies about the topic. In general, it can be very useful to learn empirically how the interrelationship between service quality, customer satisfaction, and customer loyalty performs in a new setting in order to enrich the generalization of the results from previous studies.

Te findings of this study also support some popular findings from previous research in the relationship marketing field. The hypothesis that service quality is the antecedent of customer satisfaction is confirmed in this study, which is in line with the results from previous studies (Cronin Jr. et al., 2000; Yee et al., 2010). Customer satisfaction is also validated as an antecedent of customer loyalty, which is proposed in research in both the marketing and management literature (Gillani \& Awan, 2014; Hall, 2011; Mithas, Krishnan, \& Fornell, 2005). Moreover, service quality is also significantly and positively related to customer loyalty which makes it one of the sources for improving customer loyalty. This finding is consistent with the results of previous research (Brady \& Robertson, 2001; Caceres \& Paparoidamis, 2007). In particular, customer satisfaction is confirmed as partially mediating the relationship between service quality and customer loyalty, which highlights the role of customer satisfaction as a fundamental foundation for achieving customer loyalty. This finding is also consistent with studies which view customer satisfaction as the mediators for the relationship between customer loyalty and other constructs such as customer knowledge management, relationship quality, and customer customization (Caceres \& Paparoidamis, 2007; Hu, Kandampully, \& Juwaheer, 2009).

The findings of the current study have some implications for service providers and managers. First, customer-related measures such as the customer's perception of service quality and customer satisfaction should be the primary objectives for a firm's business strategy. In other words, firms should follow a customer-oriented strategy to cope with the challenges in business nowadays since this can improve customer retention and thus help the firm to reduce the cost of marketing, improve and stabilize revenues, and adapt in a timely and suitable adequate way to changes in customers' profiles or preferences. In addition, regular monitoring and evaluation of the customer-related measures can help managers to deliver the products/services which customers value the most and thus also attract new customers. Second, this study emphasizes the need for managers to view their organizations as a complete system which consists of a lot of components and, more importantly, managers should put their efforts into the task of linking all these components together to serve a common objective. Managers can use conceptual frameworks such as the Balanced Scorecard or Service-Profit Chain as a reference point for starting to connect all the activities in the organizations. This study confirms the link between excel- 
lent business processes that result in high service quality in the banking sector with customer satisfaction and customer loyalty. This finding suggests that if managers can direct and align all the business processes in their bank towards creating a customer perception of higher service quality, customers tend to be more satisfied and their loyalty also improves. However, in order to improve business processes, managers should also consider aligning other important factors in their organizations, such as human resources or employee satisfaction.

\section{Limitations and future research}

As is the case with most research projects, this study also features some limitations that should be considered. First, the measurement scales which are used for measuring service quality and customer satisfaction are not so optimal for the purpose of this research. Service quality and customer satisfaction should be measured with more comprehensive models which are suggested in the literature, such as the SERVQUAL or National Customer Satisfaction Index methods. Unfortunately, because of the limited resources and the fact that such data is often difficult and costly to collect, this study used a direct scale to measure service quality and customer satisfaction. Second, the results presented in this study are based on the analysis of a causal model with cross-sectional data. It is not optimal because the time orders of the constructs, which are one of the important elements in causal model analysis, are ignored. Therefore, definite evidence of a causal effect cannot be inferred. Future research should attempt to collect pooled time series and cross-sectional data in order to investigate the objectives of this study. Moreover, customer satisfaction is found to mediate the relationship between customer loyalty and service quality just partly in the Vietnamese retail banking sector. This raises the question whether there are other constructs which can also explain the impacts of service quality on customer loyalty. These can be used as research questions for future research in the field.

\section{Acknowledgements}

The research for this paper was financially supported by the Internal Grant Agency of Faculty of Management and Economics, Tomas Bata University in Zlín, grant No. IGA/FaME/2016/020.

\section{References}

1. Akhtar, M. N., Hunjra, A. I., Akbar, S. W., Kashif-Ur-Rehman, \& Niazi, G. S. K. (2011). Relationship between customer satisfaction and service quality of Islamic banks. World Applied Sciences Journal, 13(3), 453-459.

2. Anderson, J. C., \& Gerbing, D. W. (1988). Structural equation modeling in practice: A review and recommended two-step approach. Psychological Bulletin, 103(3), 411-423.

3. Belás, J., \& Gabčová, L. (2014). Reasons for Satisfaction and Dissatisfaction of Bank Customers: Study from Slovakia and the Czech Republic. International Journal of Entrepreneurial Knowledge, 2(1), 4-13. doi: 10.15759/ijek/2014/v2i1/53759

4. Belás, J., \& Gabčová, L. (2016). The relationship among customer satisfaction, loyalty and financial performance of commercial banks. E\&M Economics and Management, 19 (1). dx.doi. org/10.15240/tul/001/2016-1-010

5. Belás, J., Cipovová, E., \& Demjan, V. (2014). Current trends in area of satisfaction of banks' clients in the Czech Republic and Slovakia. Transformation in Business \& Economics, 13.3(33), 219-234. 
6. Bitner, M. J. (1990). Evaluating service encounters: The effects of physical surroundings and employee responses. Journal of Marketing, 54(2), 69-82. doi:10.2307/1251871

7. Brady, M. K., \& Robertson, C. J. (2001). Searching for a consensus on the antecedent role of service quality and satisfaction: An exploratory cross-national study. Journal of Business Research, 51(1), 53-60. doi:10.1016/S0148-2963(99)00041-7

8. Brady, M. K., Cronin, J. J., \& Brand, R. R. (2002). Performance-only measurement of service quality: A replication and extension. Journal of Business Research, 55(1), 17-31. doi:10.1016/S0148-2963(00)00171-5

9. Brunner, T. A., Stöcklin, M., \& Opwis, K. (2008). Satisfaction, image and loyalty: New versus experienced customers. European Journal of Marketing, 42(9-10), 1095-1105. doi:10.1108 /03090560810891163

10. Caceres, R. C., \& Paparoidamis, N. G. (2007). Service quality, relationship satisfaction, trust, commitment and business-to-business loyalty. European Journal of Marketing, 41(7-8), 836-867. doi:10.1108/03090560710752429

11. Camarero Izquierdo, C., Gutiérrez Cillán, J., \& San Martín Gutiérrez, S. (2005). The impact of customer relationship marketing on the firm performance: A Spanish case. Journal of Services Marketing, 19(4), 234-244. doi:10.1108/08876040510605262

12. Cameran, M., Moizer, P., \& Pettinicchio, A. (2010). Customer satisfaction, corporate image, and service quality in professional services. Service Industries Journal, 30(3), 421-435. doi:10.10 $80 / 02642060802236111$

13. Chavan, J., \& Ahmad, F. (2013). Factors Affecting On Customer Satisfaction in Retail Banking: An Empirical Study. International Journal of Business and Management Invention, 2(1), $55-62$.

14. Chien, S. -, \& Tsai, C. -. (2012). Dynamic capability, knowledge, learning, and firm performance. Journal of Organizational Change Management, 25(3), 434-444. doi:10.1108/095348 11211228148

15. Chodzaza, G. E., \& Gombachika, H. S. H. (2013). Service quality, customer satisfaction and loyalty among industrial customers of a public electricity utility in Malawi. International Journal of Energy Sector Management, 7(2), 269-282. doi:10.1108/IJESM-02-2013-0003

16. Chu, P. -, Lee, G. -. \& Chao, Y. (2012). Service quality, customer satisfaction, customer trust, and loyalty in an e-banking context. Social Behavior and Personality, 40(8), 1271-1284. doi:org/10.2224/sbp.2012.40.8.1271

17. Coelho, P. S., \& Henseler, J. (2012). Creating customer loyalty through service customization. European Journal of Marketing, 46(3-4), 331-356. doi:10.1108/03090561211202 503

18. Colgate, M., \& Lang, B. (2001). Switching barriers in consumer markets: An investigation of the financial services industrynull. Journal of Consumer Marketing, 18(4), 332-347. doi:10.110 8/07363760110393001

19. Cronbach, L. J. (1951). Coefficient alpha and the internal structure of tests. Psychometrika, 16(3), 297-334. 
20. Cronin Jr., J. J., Brady, M. K., \& Hult, G. T. M. (2000). Assessing the effects of quality, value, and customer satisfaction on consumer behavioral intentions in service environments. Journal of Retailing, 76(2), 193-218.

21. Dabbolkar, P. A. (1995). A contingency framework for predicting causality between customer satisfaction and service quality. Advances in Consumer Research, 22(1), 101-108.

22. Flint, D. J., Blocker, C. P., \& Boutin, P. J. (2011). Customer value anticipation, customer satisfaction and loyalty: An empirical examination. Industrial Marketing Management, 40(2), 219-230. doi:10.1016/j.indmarman.2010.06.034

23. Fornell, C., \& Larcker, D. F. (1981). Evaluating structural equation models with unobservable variables and measurement error. Journal of Marketing Research, 18(1), 39-50. doi: $10.2307 / 3151312$

24. Gelade, G. A., \& Young, S. (2005). Test of a service profit chain model in the retail banking sector. Journal of Occupational and Organizational Psychology, 78(1), 1-22.

25. Gillani, S. U. A., \& Awan, A. G. (2014). Customer loyalty in financial sector: A case study of commercial banks in southern Punjab. International Journal of Accounting and Financial Reporting, 4(2), 587-606. doi:http://dx.doi.org/10.5296/ijafr.v4i2.6870

26. Hall, A. (2011). Antecedents and outcomes of customer loyalty in the financial services industry (Ph.D.). Available from ProQuest Central. (900575932).

27. Hassan, M. U., Malik, A. A., Imran, M., Amna, H., \& Abbas, J. (2013). Relationships among customers' perceived service quality, satisfaction and loyalty in the retail banking sector of Pakistan. World Applied Sciences Journal, 24(8), 1020-1030. doi:10.5829/idosi. wasj.2013.24.08.13254

28. Herington, C., \& Weaven, S. (2009). E-retailing by banks: E-service quality and its importance to customer satisfaction. European Journal of Marketing, 43(9), 1220-1231. doi:10.1108/03090560910976456

29. Heskett, J. L., Jones, T. O., Loveman, G. W., Sasser Jr., W. E., \& Schlesinger, L. A. (2008). Putting the service-profit chain to work. Harvard Business Review, 86(7-8), 118-129+162.

30. Hu, H., Kandampully, J., \& Juwaheer, D. D. (2009). Relationships and impacts of service quality, perceived value, customer satisfaction, and image: An empirical study. Service Industries Journal, 29(2), 111-125. doi:10.1080/02642060802292932

31. Jones, M. A., Mothersbaugh, D. L., \& Beatty, S. E. (2000). Switching barriers and repurchase intentions in services. Journal of Retailing, 76(2), 259-274.

32. Kaplan, R. S., \& Norton, D. P. (1992, Jan/Feb 1992). The balanced scorecard - measures that drive performance. Harvard Business Review, 70, 71.

33. Lam, S. Y., Shankar, V., Erramilli, M. K., \& Murthy, B. (2004). Customer value, satisfaction, loyalty, and switching costs: An illustration from a business-to-business service context. Journal of the Academy of Marketing Science, 32(3), 293-311. doi:10.1177/009207030426 3330

34. Mascarenhas, O. A., Kesavan, R., \& Bernacchi, M. (2006). Lasting customer loyalty: A total customer experience approach. Journal of Consumer Marketing, 23(7), 397-405. doi:10.1108/07 363760610712939 
35. McAlexander, J. H., Kaldenberg, D. O., \& Koenig, H. F. (1994). Service quality measurement. Journal of Health Care Marketing, 14(3), 34-40.

36. Mithas, S., Krishnan, M., \& Fornell, C. (2005). Why do customer relationship management applications affect customer satisfaction? Journal of Marketing, 69(4), 201-209. doi:10.1509/ jmkg.2005.69.4.201

37. Mittal, V., \& Kamakura, W. A. (2001). Satisfaction, repurchase intent, and repurchase behavior: Investigating the moderating effect of customer characteristics. Journal of Marketing Research, 38(1), 131-142. doi:10.1509/jmkr.38.1.131.18832

38. Munari, L., Ielasi, F., Bajetta, L. (2013). Customer Satisfaction Management in Italian Banks. Qualitative Research in Financial Markets, 5(2), 139-160. doi: 10.1108/QRFM-11-2011-0028

39. Naik, C. N. K., Gantasala, S. B., \& Prabhakar, G. V. (2010). SERVQUAL, customer satisfaction and behavioural intentions in retailing. European Journal of Social Sciences, 17(2), 200-213.

40. Oliver, R. L. (1999). Whence Consumer Loyalty? Journal of Marketing, 63, 33. doi:10.2307/1252099

41. Olorunniwo, F., Hsu, M. K., \& Udo, G. J. (2006). Service quality, customer satisfaction, and behavioral intentions in the service factory. Journal of Services Marketing, 20(1), 59-72. doi:10.1108/08876040610646581

42. Pan, Y., Sheng, S., \& Xie, F. T. (2012). Antecedents of customer loyalty: An empirical synthesis and reexamination. Journal of Retailing and Consumer Services, 19(1), 150-158. doi:10.1016/j.jretconser.2011.11.004

43. Peng, L. S., \& Moghavvemi, S. (2015). The Dimension of Service Quality and Its Impact on Customer Satisfaction, Trust, and Loyalty: A Case of Malaysian Banks. Asian Journal of Business and Accounting, 8(2).

44. Preacher, K. J., \& Hayes, A. F. (2004). SPSS and SAS procedures for estimating indirect effects in simple mediation models. Behavior Research Methods, Instruments, and Computers, 36, 717-731.

45. Ryding, D. (2010). The impact of new technologies on customer satisfaction and business to business customer relationships: Evidence from the soft drinks industry. Journal of Retailing and Consumer Services, 17(3), 224-228. doi:10.1016/j.jretconser.2010.03.008

46. Sharma, A. (2007). The metrics of relationships: Measuring satisfaction, loyalty and profitability of relational customers. Journal of Relationship Marketing, 6(2), 33-50. doi:10.1300/J366v06n02_04

47. Silvestro, R., \& Cross, S. (2000). Applying the service profit chain in a retail environment: Challenging the "satisfaction mirror". International Journal of Service Industry Management, 11(3), 244-268. doi:10.1108/09564230010340760

48. Stan, V., Caemmerer, B., \& Cattan-Jallet, R. (2013). Customer loyalty development: The role of switching costs. Journal of Applied Business Research, 29(5), 1541-1554.

49. Tayler, W. B. (2010). The balanced scorecard as a strategy-evaluation tool: The effects of implementation involvement and a causal-chain focus. Accounting Review, 85(3), 1095-1117. doi:10.2308/accr.2010.85.3.1095 
50. Teece, D. J. (2007). Explicating dynamic capabilities: The nature and microfoundations of (sustainable) enterprise performance. Strategic Management Journal, 28(13), 1319-1350. doi:10.1002/smj.640

51. Tsai, M., Tsai, C., \& Chang, H. (2010). The effect of customer value, customer satisfaction, and switching costs on customer loyalty: An empirical study of hypermarkets in taiwan. Social Behavior and Personality, 38(6), 729-740. doi:10.2224/sbp.2010.38.6.729

52. Wang, C. L., \& Ahmed, P. K. (2007). Dynamic capabilities: A review and research agenda. International Journal of Management Reviews, 9(1), 31-51. doi:10.1111/j.1468-2370.2007.00201.x

53. Yee, R. W. Y., Yeung, A. C. L., \& Cheng, T. C. E. (2011). The service-profit chain: An empirical analysis in high-contact service industries. International Journal of Production Economics, 130(2), 236-245. doi:http://dx.doi.org/10.1016/j.ijpe.2011.01.001

54. Yee, R. W. Y., Yeung, A. C. L., \& Edwin Cheng, T. C. (2010). An empirical study of employee loyalty, service quality and firm performance in the service industry. International Journal of Production Economics, 124(1), 109-120. doi:10.1016/j.ijpe.2009.10.015

\section{Contact information}

Ing. Vu Minh Ngo

Tomas Bata University in Zlin

Faculty of Management and Economics

Mostni 5139, 76001 Zlin, Czech Republic

E-mail:ngominbvu@gmail.com

Huan Hun Nguyen

University of Economics Ho Chi Minh city

School of Banking

59c Nguyen Dinh Chieu stret, District 3

Ho Chi Minh city, Vietnam

Email:Huannguyen@ueh.edu.vn 